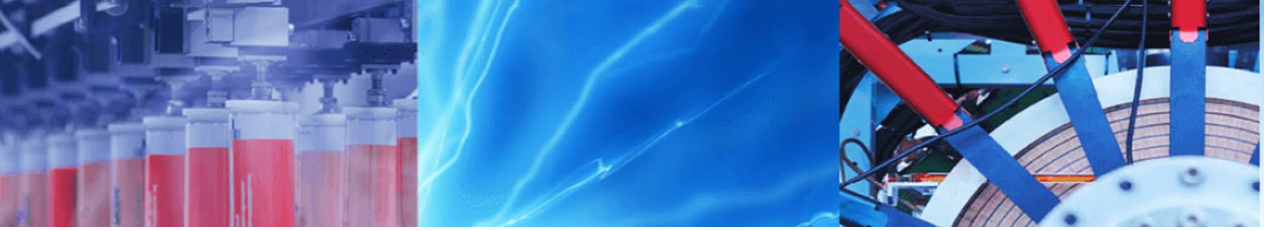

Research Article

\title{
Effect of geosynthetic reinforcement on the bearing capacity of strip footing on sandy soil
}

\author{
L. Al-Subari ${ }^{1} \cdot$ M. Hanafi ${ }^{2} \cdot$ A. Ekinci ${ }^{1}$ (I)
}

Received: 27 April 2020 / Accepted: 24 July 2020 / Published online: 8 August 2020

(c) Springer Nature Switzerland AG 2020

\begin{abstract}
Due to the increasing presence of problematic soils, expansive clays and highly compressive sand engineers are using a verity of soil improvement techniques to treat such soils. While geosynthetics are extensively used for improving soil characteristics in roads, pavements and embankments, it can also be used to increase the lack of bearing capacity of residential housing or lightweight structures constructed on sandy soils. In order to simulate site conditions in the laboratory environment, a laboratory-scale testing platform has been manufactured to assess the behaviour of geosynthetics reinforced and un-reinforced strip footing. The first group of tests were performed on the unreinforced compacted sandy soils with different densities where the other group of tests were carried out in the soil that has been reinforced individually with three different types of geosynthetic materials having distinct tensile strengths. Furthermore, interface direct shear tests and consolidated undrained triaxial tests have been carried out to determine the shear parameters which is directly influencing the bearing capacity a strip footing. Geosynthetic reinforcement has considerably enhanced the mechanical behaviour of sandy soil in regarding the type of geosynthetic. Furthermore, it was observed that coir geosynthetic has provided increased interfacial friction when compared to other geosynthetic types and improved bearing capacity. Moreover, the adopted testing method found to represent well the behaviour of such materials in the laboratory environment.
\end{abstract}

Keywords Bearing capacity · Geosynthetics · Lightweight constructions · Sand · Ground engineering

\section{Introduction}

Sandy soils are located all around the world, and it has been increasingly used for construction. However, many problems are associated with the use of sandy soils in structures such as stability of slopes, bearing capacity of foundations, and liquefaction. Many techniques were developed to overcome these problems and to enhance the ground condition [1]. Among these methods, reinforcing soil beneath the foundation is a typical practice used to improve the bearing capacity and reduce the settlement of foundations.
Practice of improving unsuitable soil for structural use has a long history. Babylonians in $2300 \mathrm{BC}$ at ancient Mesopotamia embedded woven reed mats in sand between straw clay bricks to form shallow foundations and build temples, dykes, houses etc. on compressible soils [2]. Furthermore, in ancient Greece (about 400 BC) isolated pad footings have been used to overcome differential settlement. Pad foundation excavated up to $2.6 \mathrm{~m}$ depth was back filed with layers of $0.2 \mathrm{~m}$ thick limestone gravel mix [3]. The modern practice started in the middle of the $70 \mathrm{~s}$ by Binquet and Lee [4] where authors assess the behaviour of sandy soil bearing capacity with reinforcement. Since then, the topic of improving bearing capacity of weak soils

A. Ekinci, ekincia@metu.edu.tr | ${ }^{1}$ Civil Engineering Program, Middle East Technical University, Northern Cyprus Campus, Via Mersin 10, Kalkanli, Guzelyurt, North Cyprus, Turkey. ${ }^{2}$ Civil Engineering Department, European University of Lefke, Lefke, Via Mersin 10, Turkey. 
via the use of different types of reinforcements such as geotextile, geomembrane $[5,6]$, and geogrid $[7,8]$ caught many researchers interest.

Reinforcing weak soils with geosynthetic has proven to be the most cost-effective alternative compared to all other ground improvement methods [9], along with the other benefits such as more resistance to corrosion and other chemical reactions. As a result, geosynthetic-reinforced-soil earth structures are commonly used in various geotechnical projects such as bridge supports, slopes, highways, and so on [10].

The application of such materials can be quite complex and relays on the properties and configuration of reinforcement [9] and the soil as well [11]. Therefore, understanding the mechanism of soil-geosynthetic interaction is highly important when it comes to its application. Many tests are used to characterize these materials depending on the application type. Interface direct shear can be applied for sliding failures, plane strain test can be employed for lateral deformation, and pull out test can be applied for pulling out failures [11-15]. Interface friction between the soil and geosynthetics contributes in determining the effectiveness of utilizing them as a bottom boundary layers hence improving the performance of reinforced soil foundation (RSF) against shear failure planes [16]. The friction coefficient $\mathrm{C} i$ is a parameter used to evaluate the degree of interaction between the reinforcement and the soil. The values of interaction coefficient of geosynthetics/sand are in the range of 0.6 to 1.0 estimated by Koerner [17] for geotextiles. As the interaction coefficient increased, the contribution of reinforcement positively influenced the interaction between soil and geosynthetics that in return result in enhanced mechanism. Parameters from these tests (i.e., interface direct shear and pull out test) can be directly utilized in the design $[17,18]$.

Many studies focused on the behaviour of geosynthetics using triaxial test [9, 19-24]. These studies showed that the influence of reinforcement was largely affected by many factors including specimen size, confining pressure, arrangement and spacing of the reinforcement, a form of reinforcement, number of layers and mechanical characteristics of the materials such as stiffness, friction and tensile strength. However, research showed that reinforced specimens showed higher peak strength, less reduction in residual strength, less dilation and higher cohesion. Benessalah [25] showed that geosynthetic inclusion in sandy soils increases the shear strength and reduces the lateral deformation. However, the degree of contribution depends on the number of geosynthetic layers and the confining pressure. Moreover, friction angle and cohesion also have been reported to be increased by increasing the number of geosynthetic layers. Athanasopoulos [26] reported that the volumetric response of sand was highly affected by the ratio of geosynthetics opening to the average sand size. Abdelkader et al. [22] reported that the sample preparation method also affected the compression strength of the specimens significantly.

The mechanism of bearing capacity of reinforced footings on sandy soils has been investigated by several experimental studies in the literature. Lab-scale [27-34] and field large-scale $[35,36]$ experiments have been performed to assess the performance of different footings on reinforced weak soils. Reinforcement orientation, as well as the geometry of the footing effects on the bearing capacity of RSF, have been investigated by several researchers. Badakhshan [37] and Dastpak [38] have studied the effect of load eccentricity and footing geometry on the bearing capacity and settlement behaviour of RSF. Badakhshan [37] has reported that by increasing the number of geosynthetic reinforcement, the bearing capacity increases in a higher rate in circular footing than in square footing. Moreover, eccentric loads tend to mobilize the layered reinforcement forces, although the bearing capacity is reduced by the effect of eccentricity requiring a larger dimension of reinforcement beneath the footing [38]. Shahin at el. [39] studied the load and configuration limitations of reinforced foundations. The author reported that reinforcement length that is two times longer than the width of the footing is preferable to ensure mobilization of force due to reinforcement. Lavasan and Ghazaviet [40] further reported that the mobilization of those tensile forces on the geosynthetics as a reinforcing member leads to increased bearing capacity and reduction of settlements.

There are also some analytical and numerical methods to estimate the bearing capacity [41-43]. Chen and Abu-Farsakh [42] have developed analytical equations to determine the bearing capacity of reinforced soil foundation. Khosrojerdi [44] has proposed an equation to predict the maximum settlement of RSF based on the footing geometry, soil cohesion, and friction angle as well as the properties of reinforcement material.

This study aims to investigate the contribution of geosynthetics on the settlement and bearing capacity of sandy soils. Furthermore, a small-scale laboratory testing platform was developed to predicting the actual behaviour of reinforced sand on-site. For that reason, three different types of geosynthetics were tested using the direct shear test to determine the interface friction between them and the sand. Furthermore, consolidated undrained triaxial tests were conducted to test the material under three-dimensional compression conditions. Finally, small-scale laboratory tests were carried out to mimic the conditions of the real reinforced sand on-site. 


\section{Materials}

\subsection{Sand}

A commercial Standard Sand (TS EN 196-1) was used in this study. Figure 1 shows the grain size distribution curve of the studied sand. Accordingly, the effective sizes D10, D30, and D60 have been determined and seen on Table 1. The Coefficient of Curvature $\mathrm{Cc}$, as well as the Coefficient of Uniformity $\mathrm{Cu}$, has been calculated as well. The classification of the sand has been determined according to the Unified Soil Classification System (USCS) and was found to be well-graded sand SW with angular particles. The specific gravity for the sand was found to be 2.62 and density of the tested specimens has been kept constant for the whole tests with or without reinforcement, and it is equal to $1.7 \mathrm{~g} / \mathrm{cm}^{3}$.

\subsection{Geosynthetics}

Grab Breaking Load of three different materials with same dimensions, opening and structure have been tested according to ASTM D4632-08 [45]. Results of performed tests can be seen at Table 2. It can be seen that the geosynthetic made up of steel have the highest braking load $(1.12 \mathrm{kN})$, which is followed by Coir and Polypropylene. Such a test provides simple information regarding quality control and acceptance testing.
Table 1 Physical properties of the used sand

\begin{tabular}{lr}
\hline Properties & Value \\
\hline Specific Gravity & 2.62 \\
Gravel $(4.75 \mathrm{~mm}<\mathrm{d})(\%)$ & 0.02 \\
Sand $(0.425 \mathrm{~mm}<\mathrm{d}<4.75 \mathrm{~mm})(\%)$ & 98.66 \\
Fines $(0.425<\mathrm{d})(\%)$ & 1.32 \\
D10 $(\mathrm{mm})$ & 0.13 \\
D30 $(\mathrm{mm})$ & 0.39 \\
D60 $(\mathrm{mm})$ & 0.85 \\
Mean Particle diameter $(\mathrm{mm})$ & 0.68 \\
Coefficient of curvature $(\mathrm{Cc})$ & 1.38 \\
Coefficient of uniformity $(\mathrm{Cu})$ & 6.54 \\
USCS Class & $\mathrm{SW}$ \\
\hline
\end{tabular}

\section{Methodology of testing}

\subsection{Direct shear test}

Direct shear tests have been performed according to ASTM D3080-11 [46], using a strain-controlled shear apparatus under consolidated drained conditions. The standard test cell is circular with a diameter of $60 \mathrm{~mm}$ and a height of $30 \mathrm{~mm}$. For the control samples, specimens were prepared by simply pouring a known quantity of sand through a con into the cell and distributing it equally. Two pore stones were placed both on the bottom and the top of the sample to allow drainage. Upon finishing, the sample was vibrated shortly, and the height was measured. For interface friction tests, the bottom half of the cell was filled with a dummy sample, and the geo-synthetics were glued on top of it.
Fig. 1 Grain size distribution of the used sand

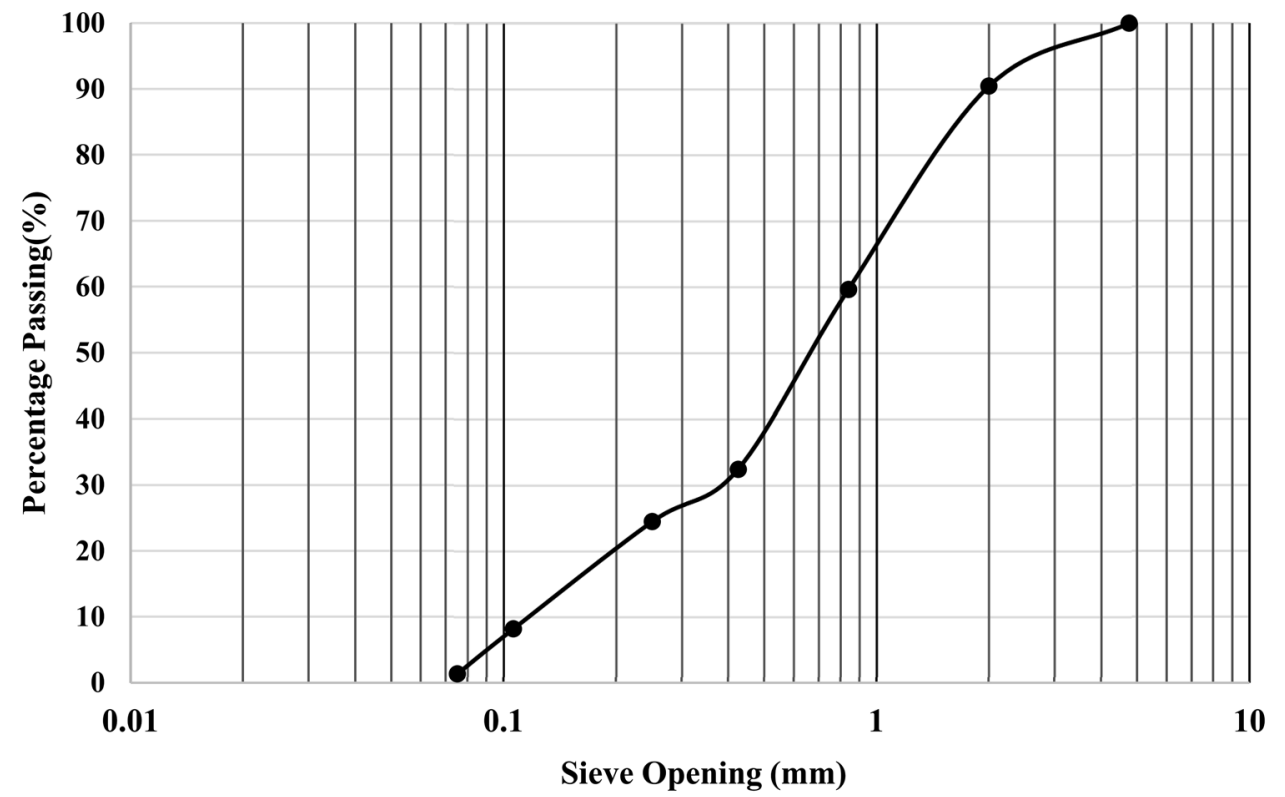

SN Applied Sciences 
Table 2 Physical properties and the tensile strength of all of the used geosynthetic

\begin{tabular}{|c|c|c|c|c|}
\hline Geosynthetic Material & $\begin{array}{l}\text { Grab Breaking } \\
\text { Load }(k N)\end{array}$ & Opening (mm) & Dimensions & $\begin{array}{l}\text { Mass per Unit Area } \\
\left(\mathrm{g} / \mathrm{m}^{2}\right)\end{array}$ \\
\hline Steel & 1.12 & 0.2 & $30 \mathrm{~mm} \times 30 \mathrm{~mm}$ & 216 \\
\hline Polypropylene & 0.62 & 0.2 & $30 \mathrm{~mm} \times 30 \mathrm{~mm}$ & 16 \\
\hline Coir & 0.84 & 0.2 & $30 \mathrm{~mm} \times 30 \mathrm{~mm}$ & 237 \\
\hline
\end{tabular}

Table 3 Performed direct shear tests and specimen properties

\begin{tabular}{llll}
\hline Short name & Geosynthetic type & $\begin{array}{l}\text { Normal } \\
\text { stress }(\mathrm{kPa})\end{array}$ & Density $\left(\mathrm{g} / \mathrm{cm}^{3}\right)$ \\
\hline DS100 & No & 100 & 1.7 \\
DS200 & No & 200 & \\
DS300 & No & 300 & \\
DSS100 & Steel & 100 & \\
DSS200 & Steel & 200 & \\
DSS300 & Steel & 300 & \\
DSP100 & Polypropylene & 100 & \\
DSP200 & Polypropylene & 200 & \\
DSP300 & Polypropylene & 300 & \\
DSC100 & Coir & 100 & \\
DSC200 & Coir & 200 & \\
DSC300 & Coir & 300 & \\
\hline
\end{tabular}

The rest of the procedure is similar to that of the control samples. All shearing tests were conducted under the same strain rate. The test consists of two stages. In the first stage, the sample is consolidated under the required confining stress, while shearing takes place in the second stage. The shearing rate $(0.3 \mathrm{~mm} / \mathrm{min})$ was calculated from the consolidation graph of the sand and kept constant for all tests. All conducted tests are summarized in Table 3.

\subsection{Consolidation undrained triaxial test}

Consolidated undrained triaxial tests were conducted in accordance with ASTM D476-95 [47]. Tests were conducted using a computer-controlled apparatus that consist of a loading frame and two pressure pumps where one of which is used for the pore pressure, and the other one to controls the cell pressure. The prepared samples were $50 \mathrm{~mm}$ in diameter and $100 \mathrm{~mm}$ in height, keeping a ratio of 2:1 as recommended by the standard. The specimens were prepared using a split mould that was attached to the bottom pedestal of the triaxial cell. Once the split mould is attached and tightened, a latex membrane is fixed inside of it, and the calculated amount of water and sand is poured with the presence of suction of approximately $-20 \mathrm{kPa}$ to hold the sample in place. The sample was poured in two layers with light tamping for each layer. For samples containing geosynthetic, a layer of geosynthetic is placed at the middle of the sample above the first layer. Upon finishing, the top cap in attached on top of the sample, and the split mould is removed. Both the top cap and the bottom pedal are siled with silicone grease to ensure the isolation of the sample. Following that, the outer cell is filled with water, and the valves are connected to the corresponding pumps. The test starts with the saturation stage in which both cell and pore pressures are raised simultaneously while marinating small deference of $50 \mathrm{kPa}$ between them. The consolidation stage starts as soon as a saturation ratio of $95 \%$ is achieved. At this stage, the cell pressure is raised to ensure the targeted, effective pressure. The duration of consolidation was maintained the same for all tests. Finial, the samples were sheared under a constant shearing rate that is similar to that used in the direct shear tests. Table 4 summarized all conducted consolidated undrained tests.

\section{SN Applied Sciences}


Table 4 Specimen properties for all conducted consolidated undrained triaxial tests

\begin{tabular}{llll}
\hline Short name & $\begin{array}{l}\text { Geosyn- } \\
\text { thetic type }\end{array}$ & $\begin{array}{l}\text { Effective confining } \\
\text { pressure }(\mathrm{kPa})\end{array}$ & Density $\left(\mathrm{g} / \mathrm{cm}^{3}\right)$ \\
\hline CUS100 & No & 100 & 1.7 \\
CUS200 & No & 200 & \\
CUSC100 & Coir & 100 & \\
CUSC200 & Coir & 200 & \\
\hline
\end{tabular}

\subsection{Small scale laboratory test}

In this part of research preparation of laboratory-scale model for calculations of settlement results for a different type of geosynthetic have been defined and can be seen in Fig. 2. In order to compact the soil in the desired density weight of sand and volume of the test tank determined. A testing tank with dimensions of $300 \times 600 \times 400 \mathrm{~mm}$ has been filled with sand and compacted in 3 equal layers, where the same compaction pattern has been applied for all layers. Pre calculated $8.75 \mathrm{~kg}$ of the total weight of the third layer, which will be built up the last $30 \mathrm{~mm}$ of the first layer, has been taken before the compaction of the last layer. A Geosynthetic of $28 \times 30 \mathrm{~mm}$ was placed on the depth of $3 \mathrm{~mm}$ below the foundation. The remaining $8.75 \mathrm{~kg}$ of sand has been used to cover the geosynthetic and same compaction pattern have been applied on the third layer. After sand laid, metal plate mimicking the strip foundation that has, $50 \mathrm{~mm}$ width $280 \mathrm{~mm}$ length and $30 \mathrm{~mm}$ thickness dimensions, place the top of the prepared sand surface. An S type load cell was connected to the centre of the footing with a steel loading piston. After that two-displacement transducer was attached on top of the footing at equal distance from the centre of loading piston. Strain control tests have been performed where $1 \mathrm{~mm} / \mathrm{min}$ of displacement was applied with the help of the load frame. Where all the load and displacement measurements were recorded digitally to a computer via a data logger.

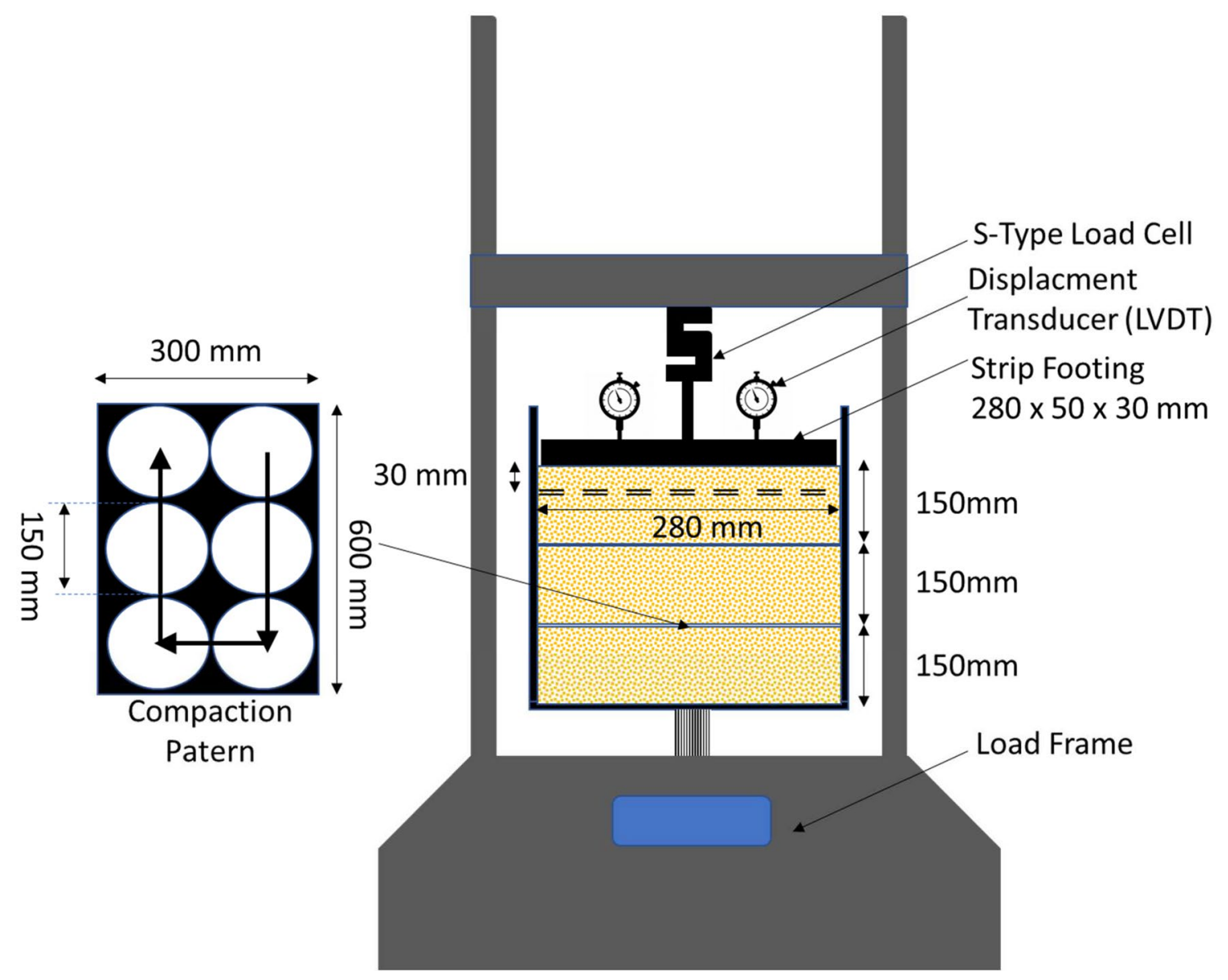

Fig. 2 Schematic diagram of the developed tank for lab scale testing 


\section{Results and discussion}

\subsection{Direct shear test}

Figures 3, 4, and 5 show interface direct shear of sand

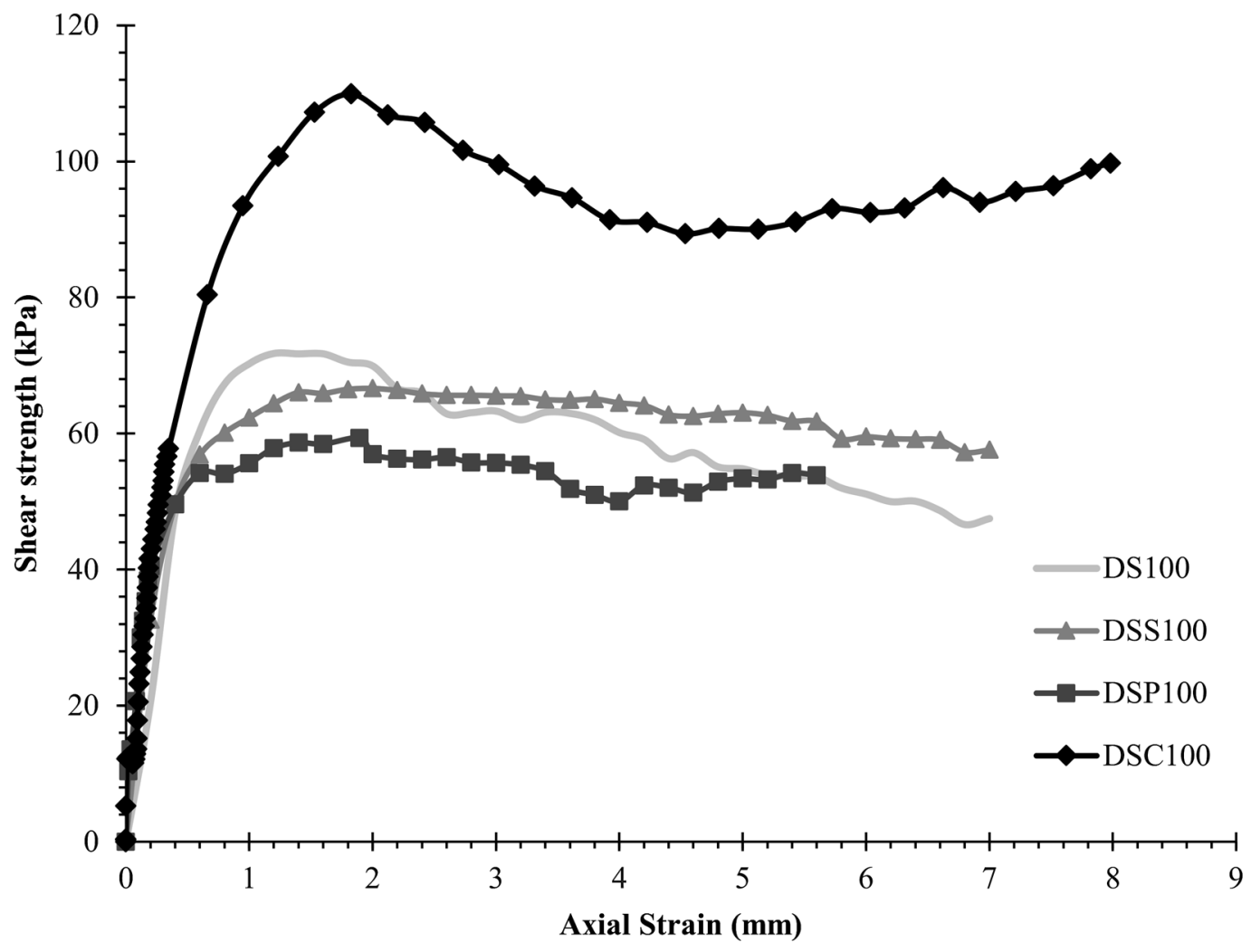

Fig. 3 Interface shear friction behaviour of sand with different types of geosynthetics under $100 \mathrm{kPa}$ normal stress

Fig. 4 Interface shear friction behaviour of sand with different types of geosynthetics under $200 \mathrm{kPa}$ normal stress

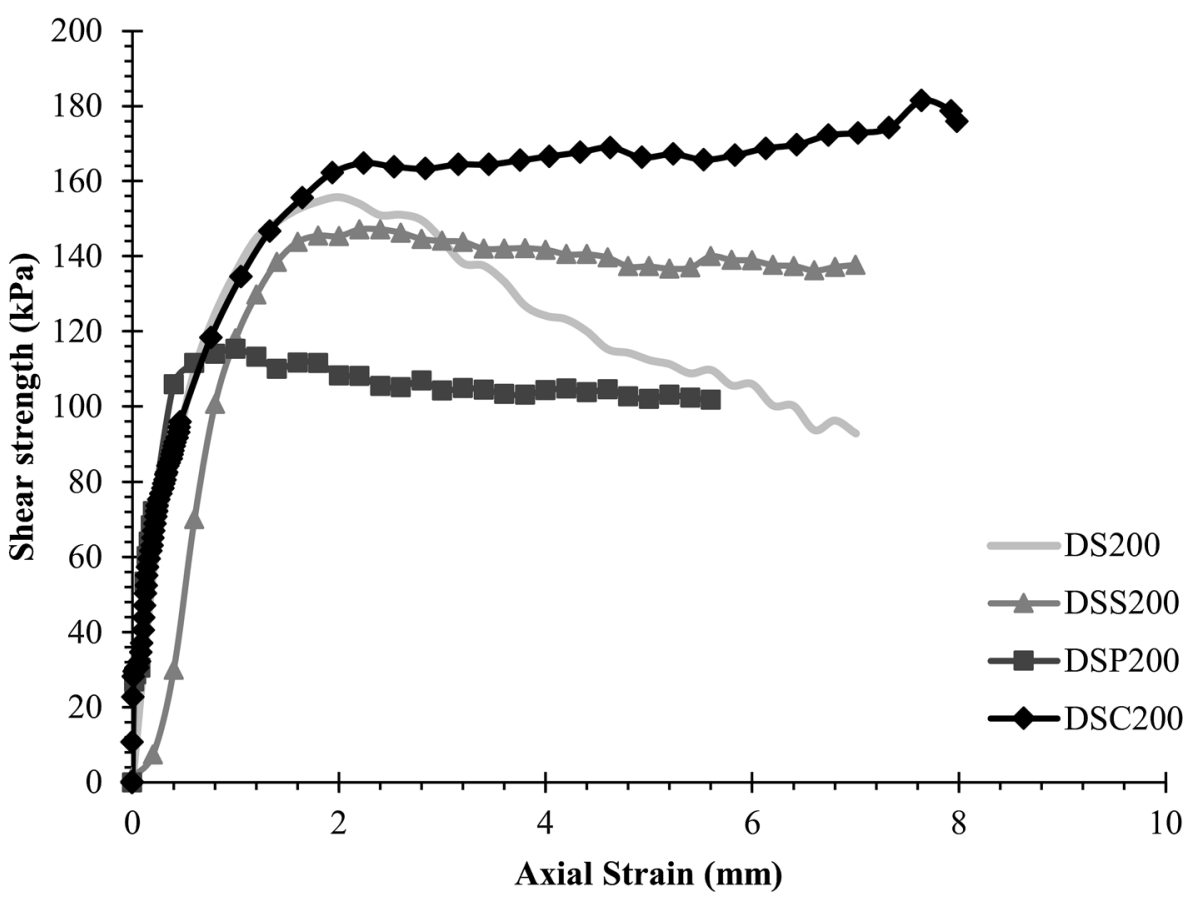


Fig. 5 Interface shear friction behaviour of sand with different types of geosynthetics under $300 \mathrm{kPa}$ normal stress

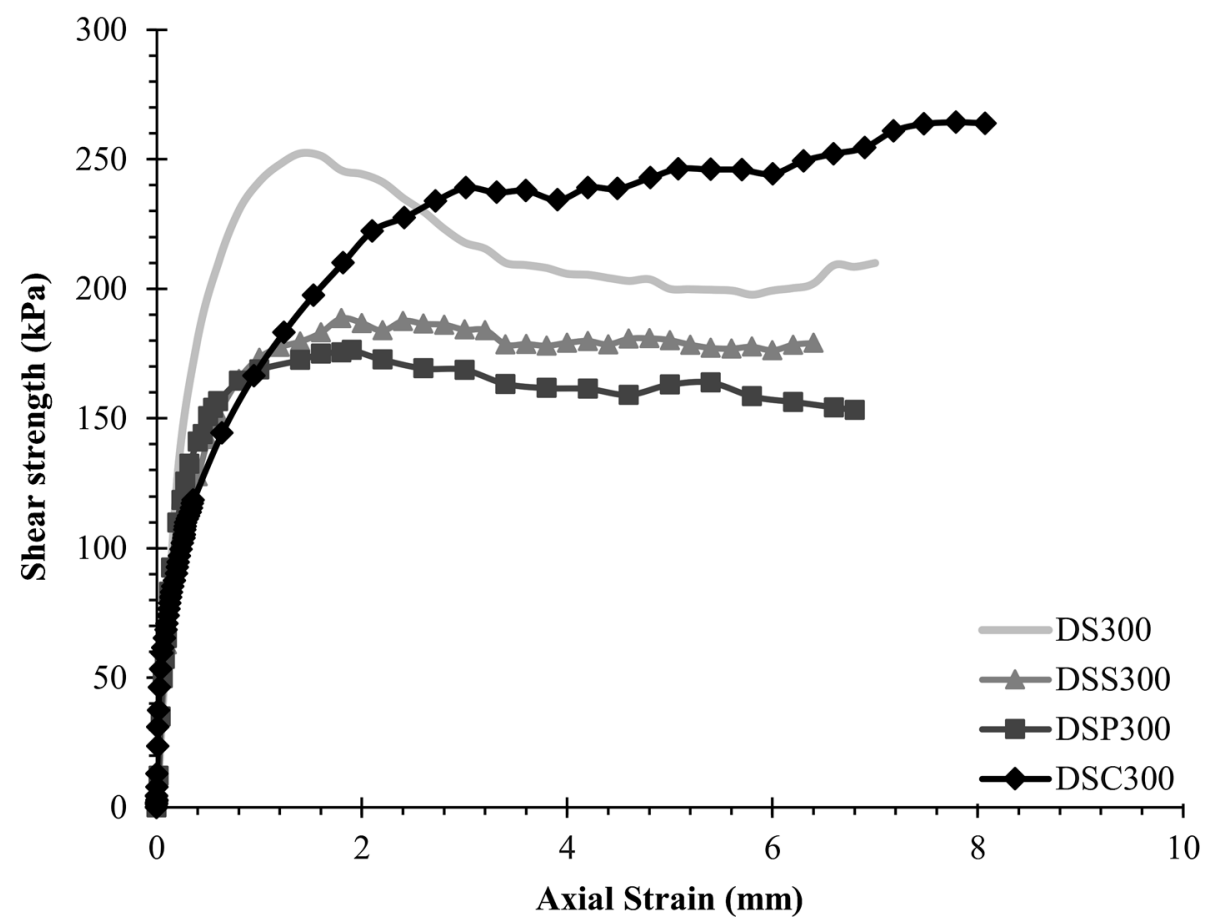

with the three types of geosynthetics under three normal stresses 100,200 , and $300 \mathrm{kPa}$, which is compared to direct shear of unreinforced sand. It can be seen that shear stresses are increasing with shear displacements until they reach the peak values then gradually decreasing to approximately constant residual stresses. The shear parameters have been found from the slope of the failure envelope illustrated in Fig. 6 . The friction angle $(\phi)$ for the sand is found to be $39.2^{\circ}$, where the cohesion was zero since cohesion-less dry samples were used.

Mohr Column failure envelopes have been plotted for the three geosynthetic types (Fig. 6).The interface friction between the geosynthetics and the sand is less than the internal friction of the sand particles which also has been reported by many researchers for instance $[12,16,48]$. The interface friction angle $(\delta)$, cohesion, interface interaction
Fig. 6 Failure envelopes of interface friction of sand with geosynthetics

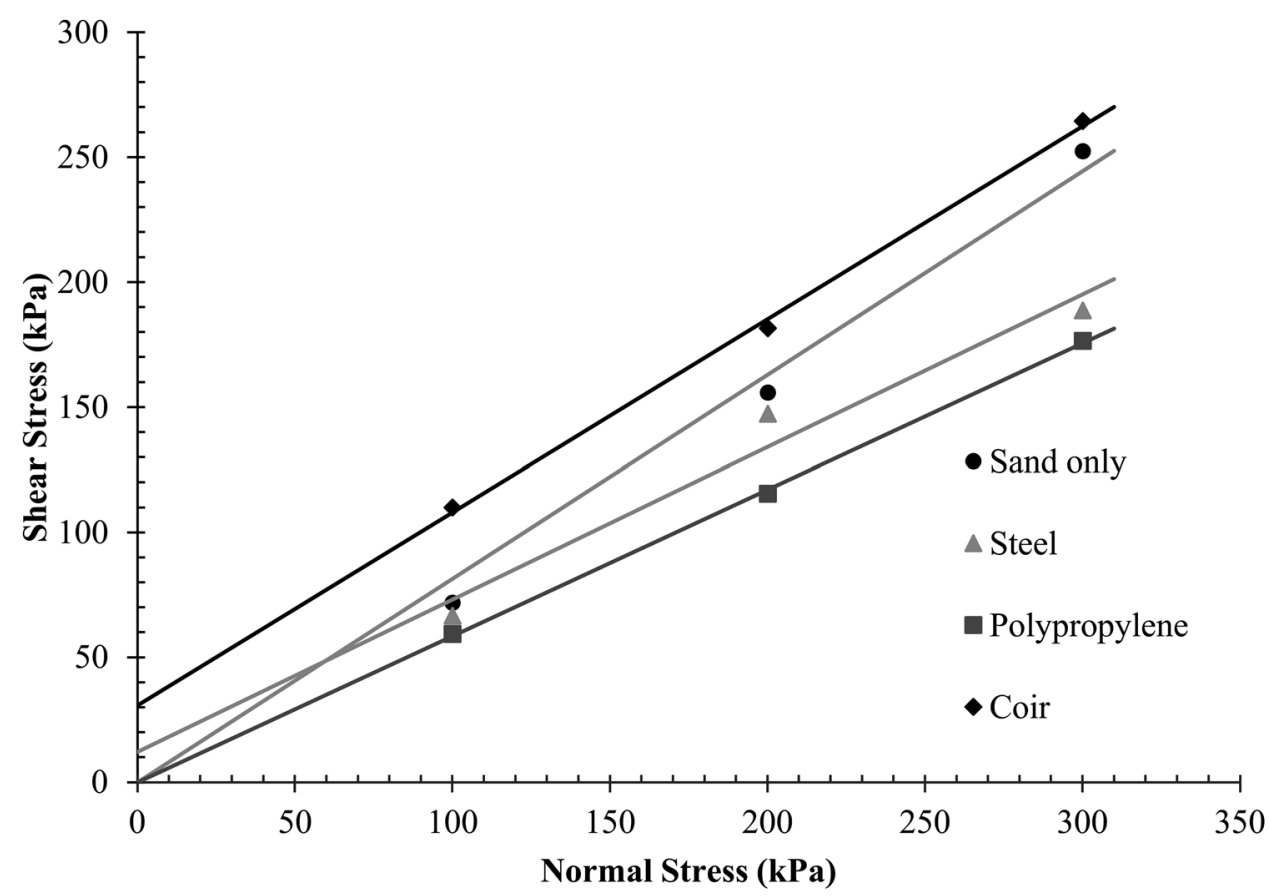

SN Applied Sciences 
Table 5 Interface shearing properties of the sand geosynthetics interaction

\begin{tabular}{llllll}
\hline Short name & Geosynthetic type & Cohesion $(\mathrm{kPa})$ & $\begin{array}{l}\text { Interface } \\
\text { Friction angle } \\
\delta\left(^{\circ}\right)\end{array}$ & $\begin{array}{l}\text { Interface friction } \\
\text { coefficient }(\tan \delta)\end{array}$ & $\begin{array}{l}\text { Interface inter- } \\
\text { action coeffi- } \\
\text { cient } C_{i}\end{array}$ \\
\hline DSS & Steel & 12.72 & 31.4 & 0.61 & 0.75 \\
DSP & Polypropylene & 0 & 30.3 & 0.58 & 0.72 \\
DSC & Coir & 30.85 & 37.7 & 0.77 & 0.95 \\
\hline
\end{tabular}

Fig. 7 Mohr-Coulomb circles and failure envelopes of sandcoir compared to unreinforced Sand from CU triaxial test

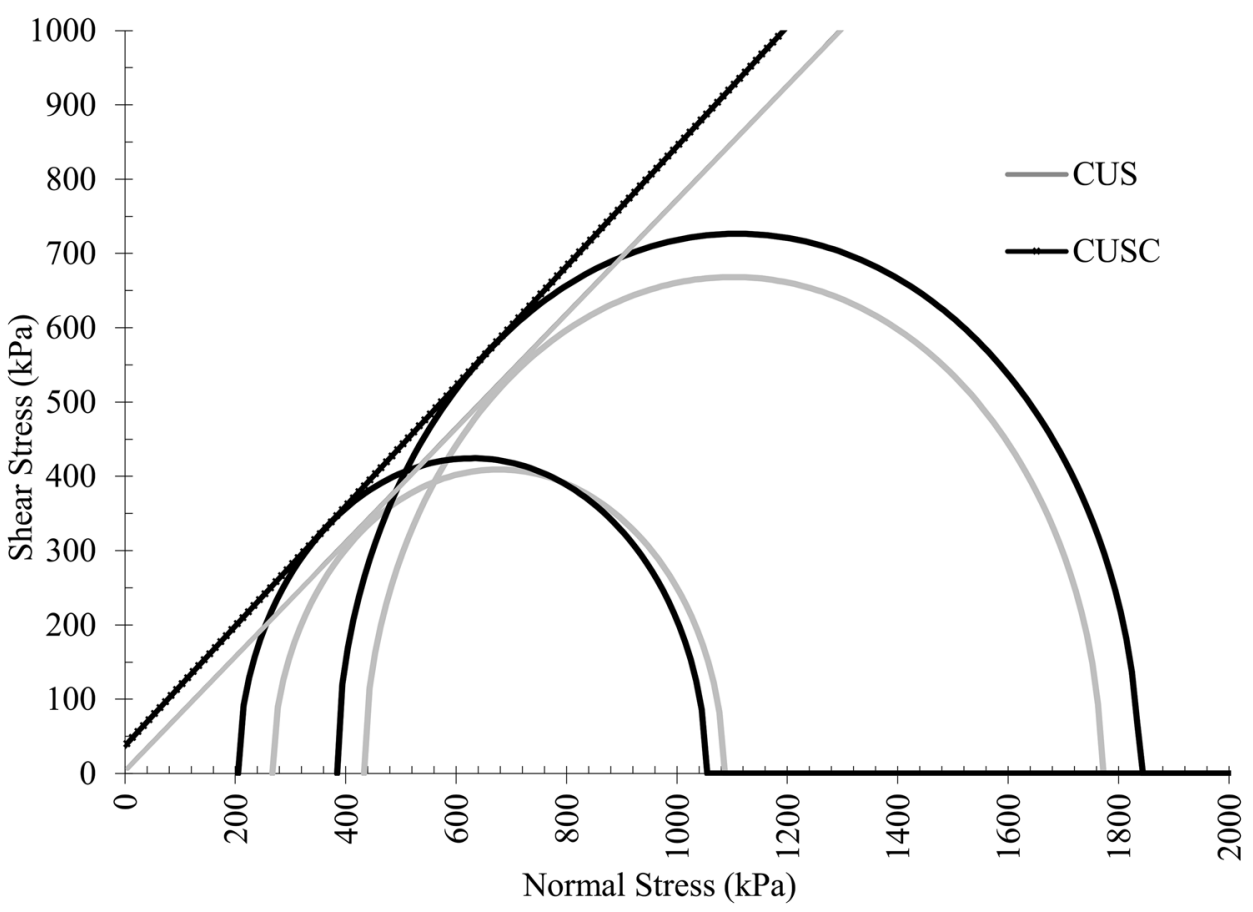

coefficient $C i$ (i.e., $C i=\tan \phi / \tan \delta$ where $\tan \phi=\tan 39.2^{\circ}$ is the sand friction coefficient and tan $\delta$ is the interface friction coefficient) between sand and the three types of geosynthetic have been determined and presented in Table 5. Coir geosynthetic has shown better performance under interface friction compared to polypropylene and steel, which qualify it to perform better as a bottom boundary beneath the sand layer carrying the footing. Therefore, enhancing the bearing capacity of the foundation [16]. The existence of some cohesion in Steel and Coir with the sand interface is due to sand particles attaching into the openings of geosynthetic and providing more surface areas that lead to an increase in contact pressure.

\subsection{Consolidation undrained triaxial test}

Based on interface direct shear results, sand reinforced with coir has shown the best performance among the three geosynthetic types used in this study. For this reason, further consolidated undrained triaxial test has been conducted on sand reinforced with the coir. Mohr-Coulomb
Table 6 Shear stress parameters for conducted triaxial tests

\begin{tabular}{llcl}
\hline Short name & $\begin{array}{l}\text { Geosynthetic } \\
\text { type }\end{array}$ & Cohesion $(\mathrm{kPa})$ & $\begin{array}{l}\text { Friction } \\
\text { angle }\left(^{\circ}\right)\end{array}$ \\
\hline CUS & NO & 3.7 & 37.6 \\
CUSC & Coir & 37.5 & 38.9 \\
\hline
\end{tabular}

circles have been sketched to show the principle stresses on samples and failure envelopes for both sand with and without reinforcement are determined (Fig. 7). The inclusion of coir reinforcement at the middle of the sand layer has increased the ultimate deviator stress of reinforced sand which is in a good agreement with other studies (e.g., [1]). It can be observed the improvement of sand behaviour with coir reinforcement where shear parameters have increased by $1.3^{\circ}$ in friction angle and almost $34 \mathrm{kPa}$ in cohesion (Table 6). Improvement in such parameters directly influence the bearing capacity as such parameters are used in determination of bearing capacity of foundations.

\section{SN Applied Sciences}




\subsection{Small scale laboratory test}

Figure 8 presents the variation of bearing pressure with footing settlement, obtained from laboratory scale load tests. It can be seen that maximum improvement is observed when the coir and steel type geosynthetic is used. Although at small strains the contribution of geosynthetics to the bearing capacity is almost neglectable, the mobilization of reinforcement material starts after almost $\mathrm{s} / \mathrm{B}=2.5 \%$ for a single layer of reinforcement [34]. Further steel type geosynthetics monitored to have higher initial stiffness when compared to coir type geosynthetic where such observation erases at high settlements. It can also be seen that the compaction effort has much more influence on the bearing capacity of the strip footing when compared to the addition of any geosynthetics. Nevertheless, the bearing capacity contribution of the steel and coir type at same density seems to be around $20 \%$. As the coir type geosynthetic material is more environmentally friendly as compared to an increase of compaction effort, it can be offered as an economical and sustainable alternative.

\section{Conclusion}

The present study investigates the impacts of geosynthetics on the settlement and load-bearing capacity of strip footing on sand. From the results presented in this study, the following conclusions can be drawn:
- The interface direct shear results revealed a variation in the interface friction between sand particles and the different types of geosynthetics. The highest interface friction coefficient as well as the adhesion value between soil and geosynthetics have been observed in coir compared to the other the two types of geosynthetics.

- Reinforcing soil with geosynthetics improved the bearing capacity of sand significantly. Moreover, using coir in reinforcement showed the highest improvement, which correlates with the interface direct shear results.

- Results from the small-scale laboratory tests show that increasing the compaction efforts can affect the bearing capacity of sand more efficiently than reinforcing with geosynthetic. However, at the same density, reinforced sand showed better performance under loading than the unreinforced sand. Coir and steel improved the initial stiffness and load-bearing capacity by $20 \%$.

- Triaxial tests results proved the effectiveness of coir in improving both the friction angle and the cohesion of sand; the friction angle was improved by $\sim 2^{\circ}$ while the cohesion was increased by $34 \mathrm{kPa}$.

- Monitored improvements will lead to an increase in load-bearing capacity and reduction in settlement of the strip foundation. Improvement in cohesion, friction angle and initial stiffness are known to have a direct influence on the load-bearing capacity and settlement of the strip foundations.

- Reuse of unwanted or disposed soil leads to a reduction in the environmental and financial impacts. Soil reinforcement with geosynthetics will enable the use
Fig. 8 Bearing capacity of unreinforced and reinforced sand with various types of geosynthetics

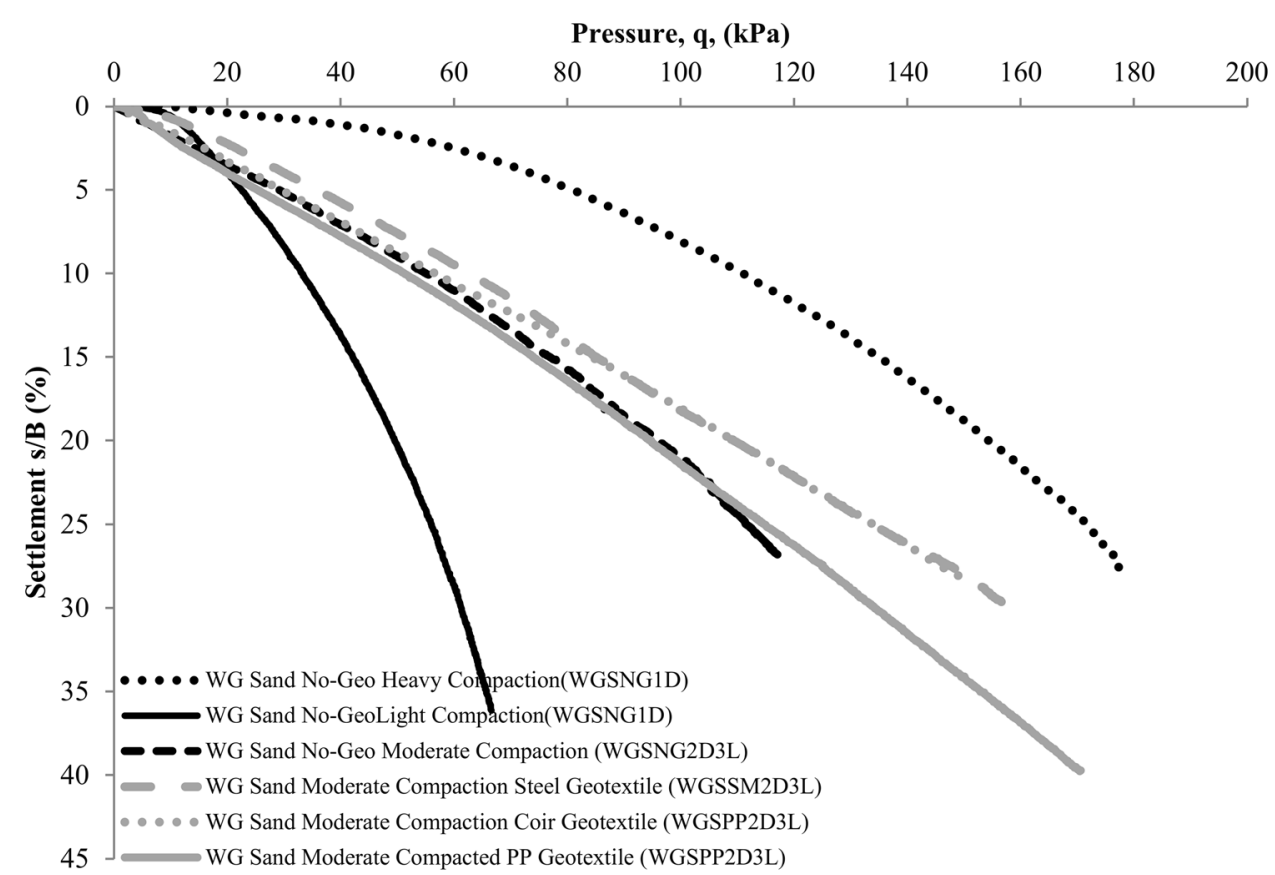


of the available soil on site. Furthermore, since this process does not require any specific tool, application on the field is conventional and straightforward.

Funding The authors express their appreciation to Office of Research Coordination and Support, Middle East Technical University, Northern Cyprus Campus for funding this research group. Scientific Research Project Code FEN-20-YG-4.

Data Availability Some or all data, models, or code that support the findings of this study are available from the corresponding author upon reasonable request.

\section{Compliance with ethical standards}

Conflict of interest I confirm that this manuscript has not been published elsewhere and is not under consideration in whole or in part by another journal. The authors have no conflict of interest to declare.

Code availability Not applicable.

\section{References}

1. Nouri S, Nechnech A, Lamri B, Lopes ML (2016) Triaxial test of drained sand reinforced with plastic layers. Arab J Geosci. https ://doi.org/10.1007/s12517-015-2017-y

2. Kérisel $J(1985)$ The history of geotechnical engineering up until 1700. In: International conference on soil mechanics and foundation engineering

3. Martin R (1965) Manuel d'architecture grecque. In: Picard AJ et al. (eds)

4. Binquet J, Lee KL (1975) Bearing capacity tests on reinforced earth slabs. ASCE J Geotech Eng Div. https://doi. org/10.1016/0148-9062(76)90517-9

5. Guido VA, Biesiadecki GL, Sullivan MJ (1985) Bearing capacity of a geotextile-reinforced foundation. In: International conference on soil mechanics and foundation engineering, pp 1777-1780

6. Huang CC, Tatsuoka F (1990) Bearing capacity of reinforced horizontal sandy ground. Geotext Geomembr. https://doi. org/10.1016/0266-1144(90)90005-W

7. Omar MT, Das BM, Puri VK, Yen SC (1993) Ultimate bearing capacity of shallow foundations on sand with geogrid reinforcement. Can Geotech J. https://doi.org/10.1139/t93-046

8. Das BM, Omar MT (1994) The effects of foundation width on model tests for the bearing capacity of sand with geogrid reinforcement. Geotech Geol Eng. https://doi.org/10.1007/BF004 29771

9. Latha MG, Murthy VS (2006) Investigations on sand reinforced with different geosynthetics. Geotech Test J 29:474-481. https ://doi.org/10.1520/gtj100439

10. Nguyen MD, Yang KH, Lee SH et al (2013) Behavior of nonwovengeotextile-reinforced sand and mobilization of reinforcement strain under triaxial compression. Geosynth Int 20:207-225. https://doi.org/10.1680/gein.13.00012

11. Palmeira EM (2009) Soil-geosynthetic interaction: modelling and analysis. Geotext Geomembr 27:368-390. https://doi. org/10.1016/j.geotexmem.2009.03.003
12. Choudhary AK, Krishna AM (2016) Experimental investigation of interface behaviour of different types of granular soil/geosynthetics. Int J Geosynth Gr Eng 2:1-11. https://doi. org/10.1007/s40891-016-0044-8

13. Markou IN (2018) Direct shear testing of sand-geotextile interfaces BT-advances in reinforced soil structures. In: Shukla SK, Guler E (eds). Springer, Cham, pp 1-12

14. Hatami K, Esmaili D (2015) Unsaturated soil-woven geotextile interface strength properties from small-scale pullout and interface tests. Geosynth Int 22:161-172. https://doi. org/10.1680/gein.15.00002

15. Horpibulsuk S, Niramitkornburee A (2010) Pullout resistance of bearing reinforcement embedded in sand. Soils Found. https://doi.org/10.3208/sandf.50.215

16. Chang L, Zhang W, Ma Y et al (2020) Geotextiles and Geomembranes Laboratory investigation of boundary e ff ect on pressure-settlement behavior of foundation soil with limited thickness involving geosynthetics. Geotext Geomembr. https ://doi.org/10.1016/j.geotexmem.2020.05.008

17. Koerner RM (2012) Designing with geosynthetics, vol 2. Xlibris Corporation, New York

18. Elias V, Christopher BR, Berg RR (2001) mechanically stabilized earth walls and reinforced soil slopes design and construction guidelines. In: Natl Highw Institute, Fed Highw Adm Washington, DC, USA Report No

19. Gray DH, ASCE AM, Al-Refeai A (1987) Behavior of fabric- versus fiber-reinforced sand. J Geotech Eng 112:804-820

20. Chandrasekaran B, Broms BB, Wong KS (1989) Strength of fabric reinforced sand under axisymmetric loading. Geotext Geomembr. https://doi.org/10.1016/0266-1144(89)90013-7

21. Zhang MX, Javadi AA, Min X (2006) Triaxial tests of sand reinforced with 3D inclusions. Geotext Geomembr. https://doi. org/10.1016/j.geotexmem.2006.03.004

22. Abdelkader B, Ahmed A, Mostéfa B, Isam S (2016) Laboratory study of geotextiles performance on reinforced sandy soil. J Earth Sci 27:1060-1070. https://doi.org/10.1007/s1258 3-015-0621-0

23. Denine S, Della N, Muhammed RD et al (2016) Effect of geotextile reinforcement on shear strength of sandy soil: laboratory study. Stud Geotech Mech 38:3-13. https://doi.org/10.1515/ sgem-2016-0026

24. Rezvani R (2019) Shearing response of geotextile-reinforced calcareous soils using monotonic triaxial tests. Mar Georesources Geotechnol. https://doi.org/10.1080/10641 19X.2019.1566936

25. Benessalah I, Arab A, Villard P et al (2016) Shear strength response of a geotextile-reinforced chlef sand: a laboratory study. Geotech Geol Eng 34:1775-1790. https://doi. org/10.1007/s10706-016-9988-7

26. Athanasopoulos GA (1993) Effect of particle size on the mechanical behaviour of sand-geotextile composites. Geotext Geomembranes. https://doi.org/10.1016/0266-1144(93)90029 $-\mathrm{N}$

27. Chen Q (2007) An experimental study on characteristics and behavior of reinforced soil foundation. digitalcommons.Isu. edu

28. Elsaied AE, Saleh NM, Elmashad ME (2015) Behavior of circular footing resting on laterally confined granular reinforced soil. HBRC J 11:240-245. https://doi.org/10.1016/j.hbrcj.2014.03.011

29. Azzam WR, Nasr AM (2015) Bearing capacity of shell strip footing on reinforced sand. J Adv Res 6:727-737. https://doi. org/10.1016/j.jare.2014.04.003

30. Abu-Farsakh M, Chen Q, Sharma R (2013) An experimental evaluation of the behavior of footings on geosynthetic-reinforced sand. Soils Found 53:335-348. https://doi.org/10.1016/j.sandf .2013 .01 .001 
31. Yamamoto K, Kusuda K (2001) Failure mechanisms and bearing capacities of reinforced foundations. Geotext Geomembr 19:127-162. https://doi.org/10.1016/S0266-1144(01)00003-6

32. Michalowski RL, Shi L (2003) Deformation patterns of reinforced foundation sand at failure. J Geotech Geoenviron Eng 129:439449. https://doi.org/10.1061/(ASCE)1090-0241(2003)129:6(439)

33. Altalhe EB, Taha MR, Abdrabbo FM (2015) Behavior of strip footing on reinforced sand slope. J Civ Eng Manag 21:376-383. https ://doi.org/10.3846/13923730.2014.890646

34. Latha GM, Somwanshi A (2009) Bearing capacity of square footings on geosynthetic reinforced sand. Geotext Geomembr 27:281-294. https://doi.org/10.1016/j.geotexmem.2009.02.001

35. Abu-Farsakh M, Chen Q, Sharma R, Zhang X (2020) Large-scale model footing tests on geogrid-reinforced foundation and marginal embankment soils. Geotech Test J 31:413-423

36. Mosallanezhad M, Hataf N, Sadat Taghavi SH (2016) Experimental and large-scale field tests of grid-anchor system performance in increasing the ultimate bearing capacity of granular soils. Can Geotech J 53:1047-1058. https://doi.org/10.1139/cgj-2015-0590

37. Badakhshan E, Noorzad A (2017) Effect of footing shape and load eccentricity on behavior of geosynthetic reinforced sand bed. Geotext Geomembr 45:58-67. https://doi.org/10.1016/j. geotexmem.2016.11.007

38. Dastpak P, Abrishami S, Sharifi S, Tabaroei A (2020) Experimental study on the behavior of eccentrically loaded circular footing model resting on reinforced sand. Geotext Geomembr. https:// doi.org/10.1016/j.geotexmem.2020.03.009

39. Shahin HM, Nakai T, Morikawa Y et al (2017) Effective use of geosynthetics to increase bearing capacity of shallow foundations. Can Geotech J 54:1647-1658

40. Lavasan AA, Ghazavi M (2012) Behavior of closely spaced square and circular footings on reinforced sand. Soils Found. https:// doi.org/10.1016/j.sandf.2012.01.006
41. Sharma R, Chen Q, Abu-farsakh M, Yoon S (2009) Analytical modeling of geogrid reinforced soil foundation. Geotext Geomembr 27:63-72. https://doi.org/10.1016/j.geotexmem.2008.07.002

42. Chen Q, Abu-Farsakh M (2015) Ultimate bearing capacity analysis of strip footings on reinforced soil foundation. Soils Found 55:74-85. https://doi.org/10.1016/j.sandf.2014.12.006

43. Kazi M, Shukla SK, Habibi D (2015) An improved method to increase the load-bearing capacity of strip footing resting on geotextile-reinforced sand bed. Indian Geotech J 45:98-109. https://doi.org/10.1007/s40098-014-0111-9

44. Khosrojerdi M, Xiao M, Qiu T, Nicks J (2019) Nonlinear equation for predicting the settlement of reinforced soil foundations. J Geotech Geoenviron Eng 145:1-8. https://doi.org/10.1061/ (ASCE)GT.1943-5606.0002027

45. ASTM (2015) Standard test method for grab breaking load and elongation of geotextiles. D4632/D4632M-15a

46. ASTM (2011) Standard test method for direct shear test of soils under consolidated drained conditions. ASTM D3080/ASTM D3080-11

47. ASTM (2002) Standard test method for consolidated undrained triaxial compression test for cohesive soils. ASTM D4767/ASTM D4767-2

48. Infante DJU, Martinez GMA, Arrua PA, Eberhardt M (2016) Shear strength behavior of different geosynthetic reinforced soil structure from direct shear test. Int J Geosynth Gr Eng. https://doi. org/10.1007/s40891-016-0058-2

Publisher's Note Springer Nature remains neutral with regard to jurisdictional claims in published maps and institutional affiliations. 